\title{
Effect of inulin and probiotic bacteria on iron availability in beans (Phaseolus vulgaris L.)
}

\author{
J. M. Laparra ${ }^{1}$, R. P. Glahn ${ }^{2}$ and D. Miller ${ }^{1}$ \\ ${ }^{1}$ Department of Food Science, Cornell University, Ithaca, NY 14853, USA and ${ }^{2}$ US Plant, Soil, and Nutrition Laboratory, \\ Agricultural Research Service, US Department of Agriculture, Ithaca, NY 14853, USA
}

Anaemia is the most common nutritional disorder in the world and Fe deficiency (ID) is implicated in a majority of these cases. Clinical studies have emphasized the importance of $\mathrm{Fe}$ in the integrity of the immune system ${ }^{(1)}$. One of the keys is poor bioavailability of Fe in the diet. Beans constitute a good source of protein for large groups of the population around the world, and can also be a good source of essential minerals such as Fe. Nevertheless, legumes also contain phytates, polyphenols, etc., which impair Fe bioavailability. Among the phytochemicals, polyphenols have been suggested to have a beneficial effect on immune cell function ${ }^{(2)}$. Prebiotics such as inulin have been suggested to have an enhancing effect on Fe absorption ${ }^{(3)}$, and can also modulate the immune system ${ }^{(4)}$. The objectives were to evaluate the effects of inulin and probiotic bacteria on Fe availability from white and red beans.

White and red beans, with and without supplemental 40 ginulin $/ \mathrm{kg}$, were subjected to an in vitro gastrointestinal digestion (pepsin, $\mathrm{pH} 2$; pancreatin, $\mathrm{pH}$ 7.2). The digests were incubated overnight with Bifidobacterium infantis (ATCC 15697) or Lactobacillus acidophilus (ATCC 11974). Aliquots were then placed in the upper chamber of cell-culture plates containing monolayers of Caco-2 cells ${ }^{(5)}$. Cell associated $\mathrm{Fe}$ and ferritin formation were used as estimates of Fe bioavailability.

Inulin by itself increased white-bean Fe uptake in Caco-2 cultures; however, no differences in ferritin formation were detected. This observation may be explained by the capacity of each ferritin molecule to bind $4000 \mathrm{Fe}$ atoms. Fermentation of both white and red beans, with or without inulin, with probiotic bacteria caused differences in Fe availability only as a function of the bacteria tested. In fermented samples higher growth rates for $B$. infantis than $L$. acidophilus were quantified, probably as a result of a faster bacteria metabolic adaptation to the media and use of nutrients in the digests. Following fermentation with $B$. infantis Fe uptake from both white and red beans was decreased in Caco-2 cells. This observation correlated with an increased total phenolic content in the digests. However, the fermentation with $L$. acidophilus resulted in a lower total phenolic content and subsequent higher Fe uptake values than controls.

These results show that inulin may enhance Fe bioavailability, and suggest that probiotic bacteria caused differences in soluble polyphenols in the digests that may explain the contrasting results from B. infantis and L. acidophilus.

\begin{tabular}{|c|c|c|c|}
\hline $\begin{array}{l}\text { Bean } \\
\text { sample }\end{array}$ & $\begin{array}{c}\text { Iron in the } \\
\text { upper chamber }(\mu \mathrm{g})\end{array}$ & $\begin{array}{c}\text { ferritin } \\
\text { (ng mg } \\
{ }^{-1} \text { protein) }\end{array}$ & $\begin{array}{c}\text { Total phenols } \\
\left(\mathrm{mg} \mathrm{Gallic}^{-1} \text { acid } \mathrm{g}^{-1}\right)\end{array}$ \\
\hline \multicolumn{4}{|c|}{ No treatment with bacteria } \\
\hline White & $2.07 \pm 0.02$ & $62.88 \pm 2.29$ & $3.03 \pm 0.08$ \\
\hline Red & $2.65 \pm 0.11$ & $3.43 \pm 1.33$ & $4.17 \pm 0.33$ \\
\hline White + Inulin & $2.08 \pm 0.29$ & $61.43 \pm 4.17$ & $3.08 \pm 0.24$ \\
\hline Red + Inulin & $2.79 \pm 0.19$ & $3.56 \pm 1.09$ & $4.05 \pm 0.48$ \\
\hline \multicolumn{4}{|c|}{ Incubated with $B$. infantis } \\
\hline White & $2.07 \pm 0.01$ & $44.15 \pm 5.21$ & $3.48 \pm 0.12$ \\
\hline Red & $2.72 \pm 0.10$ & $1.75 \pm 1.99$ & $5.45 \pm 0.33$ \\
\hline White + Inulin & $2.10 \pm 0.05$ & $50.80 \pm 8.56$ & $4.25 \pm 0.19$ \\
\hline Red + Inulin & $2.63 \pm 0.03$ & $1.61 \pm 0.41$ & $5.35 \pm 0.12$ \\
\hline \multicolumn{4}{|c|}{ Incubated with $L$. acidophilus } \\
\hline White & $2.04 \pm 0.01$ & $75.55 \pm 6.11$ & $1.85 \pm 0.28$ \\
\hline Red & $2.75 \pm 0.04$ & $6.31 \pm 1.89$ & $3.04 \pm 0.25$ \\
\hline White + Inulin & $2.13 \pm 0.03$ & $86.50 \pm 7.38$ & $1.80 \pm 0.14$ \\
\hline Red + Inulin & $2.64 \pm 0.01$ & $6.15 \pm 0.51$ & $2.95 \pm 0.32$ \\
\hline
\end{tabular}

1. Mullick S, Rusia U, Sikka M \& Faridi MA (2006) Indian J Med Res 124, 647-654.

2. Álvarez P, Alvarado C, Puerto M, Schlumberger A, Jimenez L \& De la Fuente M (2006) Nutrition 22, $913-921$

3. Yeung CK, Glahn RE, Welch RM \& Miller DD (2005) J Food Sci 70, R88-R92.

4. Watzl B, Girrbach S \& Roller M (2005) Br J Nutr 93, S49-S55.

5. Glahn RP, Lee OA, Yeung A, Goldman MI \& Miller DD (1998) J Nutr 128, 1555-1561. 